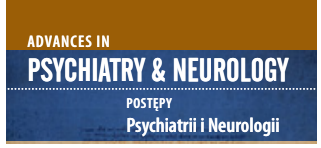

Correspondence to/Adres do korespondencji:

Alicja Zakrzewska-Sito

Department of Pharmacology

Institute of Psychiatry and Neurology

9 Sobieskiego St.

02-957 Warsaw, Poland

e-mail: azakrzewska@ipin.edu.pl

Submitted/Otrzymano: 03.09.2021

Accepted/Przyjęto do druku: 02.11.2021

\section{Searching for new drugs for the treatment of dementia-related psychosis}

\author{
Poszukiwanie nowych leków \\ w terapii psychozy zwiq̨zanej \\ z otępieniem
}

\author{
Alicja Zakrzewska-Sito (D) , Julita Kuczyńska (D)
}

Department of Pharmacology, Institute of Psychiatry and Neurology, Warsaw, Poland

\begin{abstract}
Purpose: Along with the aging process, we can observe a deterioration of cognitive functions with the simultaneous occurrence of behavioural and psychological symptoms in the elderly population. Dementia with accompanying psychosis is becoming a growing problem, not only in medical but also in social terms. This article focuses on the issues related to the occurrence of psychosis in dementia, and the need to develop new treatment.

Views: Psychosis in the elderly is different from that occurring with schizophrenia, as it is characterized by a different course and frequent resistance to treatment. In case of elderly patients, psychosis is probably associated with dysregulation of the serotonergic system. Due to the difficulties in using pharmacology in this age group, it is very important to individualize treatment. Antipsychotics are the main treatment used but they have many side effects, so in fact there is a lack of effective and safe solutions. Although pimavanserin is considered to be an effective alternative in the treatment of psychosis, it also carries a higher risk of mortality in this age group.

Conclusions: The search for new, effective and safer drugs in the treatment of dementia-related psychosis works in many directions. New animal models are emerging that allow the screening of various drug "candidates". The available research suggests that the serotoninergic system is a good direction for the search for new therapeutic solutions. As the number of elderly people with dementia increases, there is a great medical need to make it easier for them and their caregivers to function.
\end{abstract}

Key words: psychosis, BPSD, serotonergic system.

\title{
Streszczenie
}

Cel: Wraz z procesem starzenia u części społeczeństwa można zaobserwować pogorszenie funkcji poznawczych z jednoczesnym występowaniem zaburzeń behawioralnych i psychologicznych. Otępienie i współwystępująca z nim psychoza stają się coraz większym problemem nie tylko medycznym, lecz także społecznym. W artykule omówiono problematykę związaną z występowaniem psychozy w otępieniu oraz wskazano na konieczność poszukiwania nowych leków.

Poglądy: Psychoza występująca u osób starszych różni się od psychozy występującej w przebiegu schizofrenii. Zaburzenia psychotyczne u chorych w wieku podeszłym charakteryzują się innym przebiegiem i częstą opornością na leczenie, a psychoza jest prawdopodobnie związana $\mathrm{z}$ dysregulacją układu serotoninergicznego. Ze względu na trudności stosowania farmakologii u osób w wieku podeszłym bardzo ważna jest indywidualizacja leczenia. Podstawowymi lekami są leki przeciwpsychotyczne, ale ich stosowanie wiąże się z wieloma działaniami niepożądanymi. Brakuje skutecznych i bezpiecznych rozwiązań. Jak się okazuje, skuteczną alternatywą w leczeniu psychozy jest pimawanseryna, ale lek ten może również zwiększać ryzyko śmiertelności u osób starszych.

Wnioski: Poszukiwanie nowych, skutecznych i bezpieczniejszych leków w terapii psychozy związanej z otępieniem działa wielokierunkowo. Powstają nowe modele zwierzęce, które pozwalają na badanie kandydatów na leki. Dostępne badania sugerują, że dobrym kierunkiem poszukiwania nowych rozwiązań terapeutycznych jest układ serotoninergiczny. Ze względu na to, że zwiększa się liczba osób starszych z otępieniem, istnieje konieczność poszukiwania nowych leków, by ułatwić im oraz ich opiekunom funkcjonowanie. Słowa kluczowe: psychoza, BPSD, układ serotoninergiczny. 
Searching for new drugs for the treatment of dementia-related psychosis

Poszukiwanie nowych leków w terapii psychozy zwiq̨anej z otępieniem

\section{INTRODUCTION}

Increasingly higher life expectancy is one of the most distinctive demographic features of today's population. Elderly people are becoming a growing group of patients in need of special attention. As part of the aging process, a deterioration of cognitive functions is often observed with the simultaneous occurrence of behavioural and psychological disorders, the so-called BPSD (behavioural and psychological symptoms of dementia) [1]. The term was introduced by the International Psychogeriatric Society in 1994 [2]. BPSD consists of symptoms such as psychosis, agitation, irritability, anxiety, confusion, aggression, depression, apathy, sleep problems, and reduced sensitivity to emotional and physical stimuli $[3,4]$. Initially, patients display impaired cognitive functions, with the onset of fear and depression, followed by apathy, hyperactivity and anxiety [5]. In the moderate and advanced stages of this process, delusions, hallucinations and aggression might also occur at times [6].

Dementia with psychosis is becoming a particular problem in both medical and social context. This generates a growing medical necessity to meet the needs of elderly people and to improve the quality of life of their caregivers, where they are available. It would be recommendable to develop an optimal therapy that would provide for treatment, even if only of a causal sort, that could stop the progression of the disease and even reverse the symptoms of psychosis in elderly people with dementia.

The aim of this article is to present the concerns related to the occurrence of psychosis in dementia and to disseminate knowledge on the issues related to the search for new drugs in this field.

\section{DEMENTIA-RELATED PSYCHOSIS}

The following have a great influence on the appearance of psychosis among the elderly: disorders of the metabolism, perfusion in the parietal, frontal or temporal cortex, genetic factors, medications used, previous brain surgery, coexistence of other diseases, worse general health, age of the patient and possible lack of support in the immediate circles. Studies indicate that the occurrence of delusions in patients with Alzheimer's may be related not only to age, but also to symptoms of depression and aggression [7]. The appearance of hallucinations is probably associated with growing dementia, extrapyramidal symptoms, and movement disorders. Moreover, antihypertensive drugs may contribute to the appearance of delusions, and antianxiety drugs to hallucinations [8]. There are also studies that indicate genetic polymorphisms, for example of the apolipoprotein E genotype, the nicotinic receptor, and dopamine and serotonin transporters as possibly being responsible for the psychosis phenotype $[9,10]$. The appearance of symptoms of psychosis accelerates the progression of cognitive dysfunction, the appearance of depression, and worsens disability [7]. 41\% of patients with dementia/BPSD experience hallucinations, and slightly more (63\%) suffer from delusions [4]. Psychosis is more common in vascular dementia than in Alzheimer's disease $(54 \%$ vs. $36 \%)$. There is a correlation between psychotic disorders and the location of vascular changes, e.g. visual hallucinations may appear as a consequence of an occipital lobe stroke [11].

Psychosis in the elderly differs from that in middle-aged or younger people (Table 1). Visual hallucinations, delusions of being robbed, poisoned or abandoned, as well as delusional jealousy are predominant in the elderly. Delusional psychosis constitutes the highest percentage of psychosis in this age group [12], and is more common among women [13]. Psychosis usually appears only in the middle stage of the disease and progresses with worsening cognitive impairment. The most common delusions in dementia include those connected to misidentification, and somewhat less frequently are paranoid delusions [14]. In the case of misidentification, these may be not delusions but misidentification syndromes associated with cognitive disorders [14]. The term of misidentification is related to Capgras syndrome and Fregoli syndrome, which belong to delusional misidentification syndromes that may accompany mental disorders in dementia $[15,16]$. Capgras syndrome can occur as a result of damage to the cerebral cortex, which connects the facial recognition center with the limbic system responsible for assigning emotional states to recognized objects. Capgras syndrome can be a consequence of mechanical trauma, stroke and the rupture of aneurysms. The person affected by the disorder described is under the impression that relatives have been changed into doubles, and are strangers with the same appearance and behaviour as the people known to them. There is a lack of trust, and often even aggression, towards the "fraudster" [17, 18]. Another disorder that belongs to the so-called delusional misidentification syndrome is Fregoli syndrome. Patients are convinced that people, objects and places have changed or lost their identity. Such delusions may be a consequence of diabetes and hypothyroidism. Fregoli syndrome also affects people with arterial hypertension, which is often experienced by the elderly. Patients claim that people are in fact the same person who constantly changes their appearance and clothes [19, 20]. Patients may begin to develop delusions of persecution, thinking that someone is eavesdropping or watching them. Delusions in the form of being robbed or poisoned are common in the elderly, increasing their anxiety and aggression. Visual hallucinations are usually more common in Parkinson's disease and in dementia with Lewy bodies. In this case, the affected patients perceive non-existent figures and objects [21]. There are studies in which up to $90 \%$ of patients experience visual, and rarely audito- 
Table 1. Comparison of psychosis in the course of schizophrenia vs. dementia

\begin{tabular}{|c|c|}
\hline Psychosis in the course of schizophrenia & Psychosis in the course of dementia \\
\hline Auditory hallucinations dominate (commenting voices, orders) (24) & \begin{tabular}{c} 
Visual hallucinations dominate (25) \\
\hline Delusions of reference, grandeur, persecution (26)
\end{tabular} \\
\hline Sensitivity to the effects of antipsychotic drugs (29,30) & $\begin{array}{c}\text { Delusions of being robbed, poisoned or abandoned, } \\
\text { delusional jealousy (27, 28) }\end{array}$ \\
\hline $\begin{array}{c}\text { Hypothetical neurobiological background: } \\
\text { dysregulation of the dopaminergic system (32) }\end{array}$ & $\begin{array}{c}\text { Hypothetical neurobiological background: } \\
\text { dysregulation of the serotonergic system (33-36) }\end{array}$ \\
\hline
\end{tabular}

ry, hallucinations (8-13\%) in the course of Parkinson's disease [22]. Among the elderly auditory, olfactory and gustatory hallucinations usually occur as symptoms accompanying visual hallucinations [12]. When visual hallucinations occur, they should be differentiated from Charles-Bonnet syndrome, which is associated with the occurrence of ophthalmic diseases due to cataracts, glaucoma or diabetic retinopathy. The patient then sees non-existent people, animals and objects [23].

Psychotic disorders associated with BPSD are characterized by frequent resistance to treatment. Due to the difficulties in applying pharmacology, it is very important to individualize the treatment process. Non-pharmacological therapy is used as the first-line therapy [37]. In the next stage, drugs are included.

\section{NON-PHARMACOLOGICAL THERAPY}

Non-pharmacological therapy is used in patients with BPSD at the initial stage of treatment or as additional support for drug therapy.

Non-pharmacological methods include:

- training of caregivers, aimed at education, providing support, reducing stress, solving problems, teaching them to facilitate tasks and detect the factors causing specific behaviours in patients [37];

- creating a friendly, familiar and safe environment for the patient (environmental therapy);

- consolidating the skills still possessed by the patient, recreating those that have recently been lost (occupational therapy);

- memory training, reality orientation exercises (cognitive therapy);

- evoking memories with the help of stimulating materials, such as photographs or souvenirs (reminiscence therapy) [38];

- physical activity that improves mood, sleep quality, has a relaxing effect (occupational therapy) [39];

- music therapy and aromatherapy to combat depression, agitation and aggression [40-42];

- light therapy, multi-sensory stimulation - improving well-being, sleep problems;

- stimulating appropriate social behaviour, reducing anxiety (validation therapy) [38].
By using non-pharmacological therapy it is possible to alleviate some behavioural disorders in a person with psychosis, occupy their time, prevent confusion, calm them down, and improve cognitive functioning.

\section{PHARMACOLOGICAL THERAPY}

Antipsychotic drugs are among the primary medications used in the treatment of BPSD psychosis. Previously, only first-generation antipsychotic drugs, e.g. haloperidol perazine, were used. Currently, when it comes to patients with dementia, the use of these drugs is limited because it is associated with a high probability of side effects, such as muscle stiffness, tremors, depression [43]. Elderly people are more often treated with second-generation antipsychotics, which disrupt the extrapyramidal system to a lesser extent and are more effective [44]. These drugs are designed to reduce the symptoms of psychosis and the associated agitation and aggression. The clinical trials conducted to date reveal that in the treatment of Parkinson's patients with accompanying depressive symptoms, quetiapine, a benzodiazepine derivative may be the preferred choice. In the treatment of psychosis, quetiapine works by blocking the dopaminergic and serotonergic $5-\mathrm{HT}_{2}$ receptors. Moreover, it exhibits a high degree of affinity with histamine $\mathrm{H}_{1}$ and $\alpha_{1}$-adrenergic receptors, rather high level in relation to $\alpha_{2}$-adrenergic receptors, and to a lesser extent to $5-\mathrm{HT}_{1 \mathrm{~A}}$ serotonergic receptors [45]. Risperidone, olanzapine and clozapine have a similar spectrum of action. Treatment with clozapine, which blocks the dopamine $\mathrm{D}_{2}$ and $\mathrm{D}_{3}$ receptors, the serotonin $5-\mathrm{HT}_{2 \mathrm{~A}}$ and $5-\mathrm{HT}_{2 \mathrm{C}}$ receptors, the cholinergic muscarinic receptors, the $\alpha_{1}$ - and $\alpha_{2}$-adrenergic receptors, and the histamine $\mathrm{H}_{1}$ receptors is used in drug-resistant psychosis. Unfortunately, the use of clozapine carries the risk of agranulocytosis [46]. Antagonism towards $5-\mathrm{HT}_{2 \mathrm{~A}}$ receptors, e.g. in the nigrostriatal region, increases dopaminergic activity and thus reduces the likelihood of extrapyramidal side effects. Blocking the muscarinic receptors may cause disturbances in consciousness, deterioration of cognitive functions, cardiological disorders (arrhythmias, tachycardia), ophthalmic abnormalities (decreased visual acuity), constipation or difficulty urinating [47-49]. With a blockade of the $5-\mathrm{HT}_{2 \mathrm{~A}}$ and $5-\mathrm{HT}_{2 \mathrm{C}}$ receptors, patients may gain weight due to in- 
creased appetite [50]. Weight gain, somnolence and cognitive decline are associated with blocking the histamine $\mathrm{H}_{1}$ receptors. Studies support some efficacy of risperidone and olanzapine in the treatment of aggression accompanying psychosis. Risperidone shows an advantage over aripiprazole in the treatment of delusions and hallucinations in dementia [51, 52]. Aripiprazole and amisulpride act mainly on dopamine receptors and are therefore moderately effective.

As discussed, the effect of antipsychotics is not ideal because these drugs have a number of side effects and, moreover, can cause death in dementia patients due to possible cardiocerebral incidents $[43,53]$. In 2005, the US Food and Drug Administration decided to order manufacturers to include a "black box warning" on the labels of secondgeneration antipsychotic drugs due to the high risk of mortality in the elderly. Three years later, this order was extended to include second-generation drugs, i.e. clozapine, olanzapine, quetiapine and risperidone, and first-generation drugs, i.e. fluphenazine, haloperidol and chlorpromazine [54].

During the pharmacological treatment of psychosis, the need for proper control of the dosage of procognitive drugs in elderly people with dementia, i.e. cholinesterase inhibitors (rivastigmine, donepezil, galantamine) and memantine, should not be ignored. Apart from antipsychotics, antidepressants/drugs affecting insomnia, and serotonin reuptake inhibitors, i.e. trazodone and citalopram are also used in BPSD patients [55]. Citalopram has been shown to be as effective and even better-tolerated than perphenazine/risperidone in BPSD patients in two published randomized controlled trials. Escitalopram turned out to be even more effective than citalopram in the analysis of two clinical trials [56].

The effect of the available drugs is still insufficient. The lack of an effective alternative to the currently used drugs in BPSD acts as a motor in the search for new pharmacological solutions. The aim is to develop an optimal therapy allowing for treatment, even of the causal kind, that can stop the progression of the disease and even reverse the symptoms of psychosis in the elderly. The priority is to alleviate the symptoms of psychosis, depression, anxiety syndromes or cognitive disorders without disturbing motor functions.

\section{SEARCHING FOR NEW SOLUTIONS IN THE TREATMENT OF PSYCHOSIS IN THE ELDERLY}

The search for new, effective and safer drugs for BPSD goes in many directions. A review of clinical trials on the treatment of dementia-related psychosis reveals that the best alternative to clozapine and quetiapine so far is the treatment of patients with pimavanserin, which affects the serotonin receptors $[36,57]$. This drug was approved by the FDA (Food and Drug Administration) in 2016 for the treatment of psychosis in Parkinson's disease. In vitro studies indicated its inverse agonism at the $5-\mathrm{HT}_{2 \mathrm{~A}}$ receptors. Pimavanserin works in the treatment of hallucinations and delusions in the course of psychosis in the elderly. In a multicenter phase III study, its effect in the treatment of Parkinson's disease psychosis was tested. After applying the Scale for the Assessment of Positive Symptoms (SAPS), a 37\% improvement in patients' condition was observed [36]. In a 12-week phase II clinical trial in patients with Alzheimer's disease, a significant pimavanserin treatment effect was found compared to placebo (delta -1.84 , Cohen $d$-effect size 0.32 ). The effect was as assessed by using the NPI-NH (Neuropsychiatric Inventory-Nursing Home questionnaire quantifying behavioural changes in dementia). Moreover, this drug did not cause side effects on the extrapyramidal system and cognitive functions [58]. In another study, the use of pimavanserin gave better results in patients with more severe psychosis (delta -4.43 , Cohen $d$-effect size 0.73 ). An over $30 \%$ improvement was achieved in $88.9 \%$ of patients [59]. In addition, a phase III clinical trial has recently been completed, to assess the efficacy of pimavanserin versus placebo in preventing the recurrence of psychotic symptoms in patients with dementia-related psychosis. The study included patients with various forms of dementia, i.e. dementia with Lewy bodies, dementia in Parkinson's disease, frontotemporal dementia and vascular dementia. The results suggest that pimavanserin reduces the risk of the occurrence of psychosis by 2.8 times compared to placebo in patients with dementia [60]. However, caution should be exercised when using pimavanserin as it may cause QT prolongation and even lead to death (there is a "black box warning" on the label).

A multicenter, randomized, 12-week phase III clinical trial of brexpiprazole in the treatment of agitation in Alzheimer's disease was completed recently. The study involved patients living in institutional or care facilities. This antipsychotic drug has been approved by the FDA for the treatment of schizophrenia. It is active mainly at the $5-\mathrm{HT}_{2}$ receptors, but is also a partial agonist at the $5-\mathrm{HT}_{1 \mathrm{~A}}$, $\mathrm{D}_{2}$ and $\mathrm{D}_{3}$ receptors. The double-blind method with a 30-day observation was used. The efficacy, safety and tolerability of two doses of brexpiprazole ( $1 \mathrm{mg} /$ day and $2 \mathrm{mg} /$ day) were assessed. An improvement in agitation symptoms was shown compared with patients given the placebo. Brexpiprazole has been shown to be well tolerated. Side effects, such as insomnia, somnolence and residual agitation, have been reported [61]. Similar results were obtained in a 12-week phase III trial conducted in parallel [61].

Another drug that seems interesting in this context is lithium. As is well known, lithium is perfect for the treatment of bipolar disorder and other psychotic disorders involving agitation. In a recent phase II clinical trial, the efficacy of low doses (150-600 mg/day) in the treat- 
ment of agitation/aggression with and without psychosis in patients with Alzheimer's disease was investigated. Work is currently underway to submit the results of this study. If lithium proves to have been effective, it will go to the third phase of research [62].

\section{ANIMAL MODELS OF DEMENTIA-RELATED PSYCHOSIS}

Animal models play a significant role in the search for new drug "candidates". There are models which reflect changes in the brain of people with Alzheimer's psychosis: transgenic mice overexpressing APP (amyloid precursor protein), $3 \mathrm{xTg}-\mathrm{AD}$ - a model containing mutations of the APP gene, presenilin $1 \mathrm{M} 146 \mathrm{~V}$ and tau P301L protein, and the $5 \mathrm{xFAD}$ model - associated with the accumulation of $\beta$-amyloid in the brain and a high content of $A \beta 42$ as a result of the use of two human transgenes: the transgene encoding the APP protein with the "Swedish", "London" and "Florida" mutations and the transgeneencoding presenilin-1 with the M156L and L286W mutation [63]). In patients with Alzheimer's disease, an increased density of amyloid plaques, neurofibrillary tangles in the middle frontal cortex, and an increased level of abnormal tau protein in the entorhinal or temporal cortex are found [64]. The presented animal models based on genetic modifications in the future may be used in the search for new drugs acting on the psychotic symptoms of BPSD, i.e. aggression and agitation.

Another animal example that is likely to become a model of dementia-related psychosis is the natural model of spontaneous head twitching (SHT) in elderly rats over 18 months of age [65]. It turns out that with age some rats spontaneously begin to twitch their heads. Specific changes in the behaviour of aging rats resemble the behaviour of young animals following the administration of 5- $\mathrm{HT}_{2 \mathrm{~A}}$ agonists, i.e. LSD (D-lysergic acid diethylamide) and DOI (2,5-dimethoxy-4-iodoamphetamine). These psychotomimetic substances induce head twitches in rodents, a behaviour that may resemble the symptoms of psychosis in schizophrenic patients, and these behaviours are undoubtedly based on disturbances in serotonergic transmission [66, 67]. It has been observed that spontaneous head twitches in elderly rats can be inhibited by ketanserin, a $5-\mathrm{HT}_{2 \mathrm{~A}}$ receptor antagonist, and pimavanserin, and enhanced by DOI, a $5-\mathrm{HT}_{2 \mathrm{~A} / 2 \mathrm{C}}$ agonist. No effect at all of amisulpride, an antagonist of $\mathrm{D}_{2}$ and $\mathrm{D}_{3}$ receptors, has been observed. Studies carried out on elderly rats twitching their heads spontaneously suggest that the serotonergic system plays an essential role in the psychosis of elderly people with dementia, and that new compounds should be developed in this direction [65].

\section{THE ROLE OF THE SEROTONERGIC SYSTEM IN PSYCHOSIS IN THE ELDERLY}

Based on the available literature, it can be concluded that not only the dopaminergic system is responsible for psychosis in dementia, but also the serotonergic system. This is indicated by the differences between psychosis in the course of dementia and schizophrenia (Table 1). The role of the serotonergic system can be associated with the occurrence of visual and auditory hallucinations in patients with Alzheimer's disease, associated with polymorphisms of the genes encoding serotonin receptors [68]. It is known that $5-\mathrm{HT}_{6}$ receptors, which are located only in the central nervous system, in particular in the limbic and cortical parts, are responsible for the cognitive sphere and well-being and are associated with the appearance of psychotic symptoms in patients with Alzheimer's dementia $[34,69]$. In patients with Alzheimer's disease a lower density of $5-\mathrm{HT}_{2 \mathrm{~A}}$ and $5-\mathrm{HT}_{6}$ receptors in the prefrontal cortex is observed compared to healthy elderly people [34]. The effect of the serotonin receptors $5-\mathrm{HT}_{1 \mathrm{~A}}, 5-\mathrm{HT}_{2}$, $5-\mathrm{HT}_{3}, 5-\mathrm{HT}_{4}$ and $5-\mathrm{HT}_{6}$ on the change of cognitive functions, mood disorders or psychosis is observed in patients with Parkinson's disease [35]. The effect of 5- $\mathrm{HT}_{7}$ antagonists in models of psychosis is also apparent. In a study by Waters et al. (2012) SB-269970, a 5- $\mathrm{HT}_{7}$ antagonist attenuated amphetamine-induced rising on the hind limbs and axial circulation, and phencyclidine-induced hyperlocomotion in rats in an open field study [70]. Similarly, in the case of lurasidone, which is antagonistic to $5-\mathrm{HT}_{7}$ and shows partial agonism towards the $5-\mathrm{HT}_{1 \mathrm{~A}}$ receptor in relation to the $5-\mathrm{HT}_{1 \mathrm{~A}}$ receptor, it alleviates the deficits caused by the administration of phencyclidine [71].

\section{CONCLUSIONS}

To conclude, due to the fact that the elderly with dementia are beginning to constitute an increasing group of patients, it is very important to pay attention to their quality of life. Elderly people often find it difficult to cope. Their life in society can be disturbed, as can that of their caregivers. Psychosis is a very big problem, so finding new pharmacological solutions to treat dementia-related psychosis/BPSD is of great importance. There are no effective and safe drugs for psychotic disorders in this group of patients. The serotoninergic system seems to be a good direction to follow in the search for new drugs. This is indicated by the action of available drugs, the location of receptors, and the natural model of spontaneous head twitching (SHT) in elderly rats. 
Searching for new drugs for the treatment of dementia-related psychosis

Poszukiwanie nowych leków w terapii psychozy związanej z otępieniem

\section{Conflict of interest/Konflikt interesu}

Absent./Nie występuje.

Financial support/Finansowanie

Absent./Nie występuje.

\section{References/Piśmiennictwo}

1. Hersch EC, Falzgraf S. Management of the behavioral and psychological symptoms of dementia. Clin Interv Aging 2007; 2: 611-621.

2. American Geriatrics Society. Five things physicians and patients should question. In: Choosing wisely. ABIM Foundation; 2013.

3. Carson S, McDonagh MS, Peterson K. A systematic review of the efficacy and safety of atypical antipsychotics in patients with psychological and behavioral symptoms of dementia. J Am Geriatr 2006; 54: 354-361.

4. Jeste DV, Blazer D, Casey D, Meeks T, Salzman C, Schneider L, et al. ACNP White Paper: update on use of antipsychotic drugs in elderly persons with dementia. Neuropsychopharmacol 2008; 33: 957-970.

5. Holmes C, Wilkinson D, Dean C, Vethanayagam S, Olivieri S, Langley A, et al. The efficacy of donepezil in the treatment of neuropsychiatric symptoms in Alzheimer disease. Neurology 2004; 63: 214-219.

6. Health Canada. Updated safety information for Risperdal ${ }^{*}$ (risperidone) in elderly dementia patients, announced in Canada by Janssen-Ortho Inc. https://healthycanadians.gc.ca/recall-alert-rappel-avis/hc-sc/2015/43797aeng.php (Accessed: 09.08.2020).

7. Sobów T. Benzodiazepiny u pacjentów w podeszłym wieku. MWP 2012; 2: 1-6.

8. Bassiony MM, Steinberg MS, Warren A, Rosenblatt A, Baker AS, Lyketsos CG. Delusions and hallucinations in Alzheimer's disease: prevalence and clinical correlates. Int J Geriatr Psychiatry 2000; 15: 99-107.

9. DeMichele-Sweet MA, Sweet RA. Genetics of psychosis in Alzheimer's disease: a review. J Alzheimers Dis 2010; 19: 761-780.

10. Flirski M, Sobow T, Kloszewska I. Behavioural genetics of Alzheimer's disease: a comprehensive review. Arch Med Sci 2011; 7: 195-210.

11. Ostling S, Gustafson D, Blennow K, Börjesson-Hanson A, Waern M. Psychotic symptoms in a population-based sample of 85-year-old individuals with dementia. J Geriatr Psychiatry Neurol 2011; 24: 3-8.

12. Ropacki SA, Jeste DV. Epidemiology of and risk factors for psychosis of Alzheimer's disease: a review of 55 studies published from 1990 to 2003. Am J Psychiatry 2005; 162: 2022-2030.

13. Axmon A, Sandberg M, Ahlström G. Gender differences in psychiatric diagnoses in older people with intellectual disability: a register study. BMC Psychiatry 2017; 17: 192.

14. Schneider LS, Dagerman KS. Psychosis of Alzheimer's disease: clinical characteristics and history. J Psychiatr Res 2004; 38: 105-111.

15. Josephs KA. Capgras syndrome and its relationship to neurodegenerative disease. Arch Neurol 2007; 64: 1762-1766.

16. Thaipisutikul P, Lobach I, Zweig Y, Gurnani A, Galvin JE. Capgras syndrome in dementia with Lewy bodies. Int Psychogeriatr 2013; 25: 843-849.

17. Todd J, Dewhurst K, Wallis G. The syndrome of Capgras. Br J Psychiatry 1981; 139: 319-327.

18. Frazer SJ, Roberts JM. Three cases of Capgras' syndrome. Br J Psychiatry 1994; 164: 557-559.

19. Mojtabai R. Fregoli syndrome. Aust N Z J Psychiatry 1994; 28: 458-462.

20. Langdon R, Connaughton E, Coltheart $M$. The Fregoli delusion: a disorder of person identification and tracking. Top Cogn Sci 2014; 6: 615-631.

21. Greene P, Cote L, Fahn S. Treatment of drug-induced psychosis in Parkinson's disease with clozapine. Adv Neurol 1993; 60: 703-706.

22. Graham JM, Grunewald RA, Sagar HJ. Hallucinosis in idiopathic Parkinson's disease. J Neurol Neurosurg Psychiatry 1997; 63: 434-440.

23. Pang L. Hallucinations experienced by visually impaired: Charles Bonnet syndrome. Optom Vis Sci 2016; 93 : 1466-1478.

24. Hugdahl K, Løberg EM, Specht K, Steen VM, van Wageningen H, Jørgensen HA. Auditory hallucinations in schizophrenia: the role of cognitive, brain structural and genetic disturbances in the left temporal lobe. Front Hum Neurosci 2008; 1: 6.

25. Swann P, O'Brien JT. Management of visual hallucinations in dementia and Parkinson's disease. Int Psychogeriatr 2019; 31: 815-836.

26. Gałecki P, Szulc A. Psychiatria. Wrocław: Edra Urban \& Partner; 2018, p. 165.

27. Rudaleviciene P, Adomaitiene V, Stompe T, Narbekovas A, Meilius K, Raskauskiene N, et al. Delusions of persecution and poisoning in patients with schizophrenia: sociocultural and religious background. Medicina (Kaunas) 2010; 46: 185-192.

28. Gabryelewicz T. Zaburzenia zachowania oraz zaburzenia psychotyczne i afektywne w otępieniu. Pol Przegl Neurol 2007; 3: 90-96. 
29. Schulze J, Glaeske G, van den Bussche H, Kaduszkiewicz H, Koller D, Wiese B, et al. Prescribing of antipsychotic drugs in patients with dementia: a comparison with age-matched and sex-matched non-demented controls. Pharmacoepidemiol Drug Saf 2013; 22: 1308-1316.

30. Werner FM, Coveñas R. Safety of antipsychotic drugs: focus on therapeutic and adverse effects. Expert Opin Drug Saf 2014; 13: 1031-1042.

31. Jeste DV, Maglione JE. Atypical antipsychotics for older adults: are they safe and effective as we once thought? J Comp Eff Res 2013; 2: 355-358.

32. Brisch R, Saniotis A, Wolf R, Bielau H, Bernstein HG, Steiner J, et al. The role of dopamine in schizophrenia from a neurobiological and evolutionary perspective: old fashioned, but still in vogue. Front Psychiatry 2014; 5: 47.

33. Lanctôt KL, Herrmann N, Mazzotta P. Role of serotonin in the behavioral and psychological symptoms of dementia. J Neuropsychiatry Clin Neurosci 2001; 13: 5-21.

34. Lorke DE, Lu G, Cho E, Yew DT. Serotonin 5- $\mathrm{HT}_{2 \mathrm{~A}}$ and 5- $\mathrm{HT}_{6}$ receptors in the prefrontal cortex of Alzheimer and normal aging patients. BMC Neurosci 2006; 7: 36.

35. Ohno Y, Shimizu S, Tokudome K, Kunisawa N, Sasa M. New insight into the therapeutic role of the serotonergic system in Parkinson's disease. Prog Neurobiol 2015; 134: 104-121.

36. Cummings J, Isaacson S, Mills R, Williams H, Chi-Burris K, Corbett A, et al. Pimavanserin for patients with Parkinson's disease psychosis: a randomised, placebo-controlled phase 3 trial. Lancet 2014; 383: 533-540.

37. Brodaty $\mathrm{H}$, Arasaratnam C. Meta-analysis of nonpharmacological interventions for neuropsychiatric symptoms of dementia. Am J Psychiatry 2012; 169: 946-953.

38. Długosz-Mazur E, Bojar I, Gustaw K. Niefarmakologiczne metody postępowania u chorych z otępieniem. Med Og Nauk Zdr 2013; 19: 458-462.

39. Schneider LS, Pollock VE, Lyness SA. A metaanalysis of controlled trials of neuroleptic treatment in dementia. J Am Geriatr Soc 1990; 38: 553-563.

40. O'Connor DW, Ames D, Gardner B, King M. Psychosocial treatments of behavior symptoms in dementia: a systematic review of reports meeting quality standards. Int Psychogeriatr 2009; 21: 225-240.

41. O’Neil ME, Freeman M, Christensen V, Telerant R, Addleman A, Kansagara D. A systematic evidence review of nonpharmacological interventions for behavioral symptoms of dementia. Washington DC: DVA(US); 2011.

42. Kales HC, Gitlin LN, Lyketsos CG. Assessment and management of behavioral and psychological symptoms of dementia. BMJ 2015; 350: h369.

43. Sink KM, Holden KF, Yaffe K. Pharmacological treatment of neuropsychiatric symptoms of dementia: a review of the evidence. JAMA 2005; 293: 596-608.

44. Liperoti R, Pedone C, Corsonello A. Antipsychotics for the treatment of behavioral and psychological symptoms of dementia (BPSD). Curr Neuropharmacol 2008; 6: 117-124.

45. Onor ML, Saina M, Aguglia E. Efficacy and tolerability of quetiapine in the treatment of behavioral and psychological symptoms of dementia. Am J Alzheimers Dis Other Demen 2006; 21: 448-453.

46. Wiciński M, Węclewicz MM. Clozapine-induced agranulocytosis/granulocytopenia: mechanisms and monitoring. Curr Opin Hematol 2018; 25: 22-28.

47. Robinson L, Harbaran D, Riedel G. Visual acuity in the water maze: sensitivity to muscarinic receptor blockade in rats and mice. Behav Brain Res 2004; 151: 277-286.

48. Ellis JR, Ellis KA, Bartholomeusz CF, Harrison BJ, Wesnes KA, Erskine FF, et al. Muscarinic and nicotinic receptors synergistically modulate working memory and attention in humans. Int J Neuropsychopharmacol 2006; 9: 175-189.

49. Andersson KE, Campeau L, Brian Olshansky B. Cardiac effects of muscarinic receptor antagonists used for voiding dysfunction. Br J Clin Pharmacol 2011; 72: 186-196.

50. Berglund ED, Liu C, Sohn JW, Liu T, Kim MH, Lee CE, et al. Serotonin 2C receptors in pro-opiomelanocortin neurons regulate energy and glucose homeostasis. J Clin Invest 2013; 123: 5061-5070.

51. Ballard C, Waite J. The effectiveness of atypical antipsychotics for the treatment of aggression and psychosis in Alzheimer's disease. Cochrane Database Syst Rev 2006; 25: CD003476.

52. De Deyn P, Jeste DV, Swanink R, Kostic D, Breder C, Carson WH, Iwamoto T. Aripiprazole for the treatment of psychosis in patients with Alzheimer's disease: a randomized, placebo-controlled study. J Clin Psychopharmacol 2005; 25: 463-467.

53. Mazzucco S, Cipriani A, Barbui C, Monaco S. Antipsychotic drugs and cerebrovascular events in elderly patients with dementia: a systematic review. Mini Rev Med Chem 2008; 8: 776-783.

54. Dorsey ER, Rabbani A, Gallagher SA, Conti RM, Alexander GC. Impact of FDA black box advisory on antipsychotic medication use. Arch Intern Med 2010; 170: 96-103.

55. Pollock BG, Mulsant BH, Rosen J. Comparison of citalopram, perphenazine, and placebo for the acute treatment of psychosis and behavioral disturbances in hospitalized, demented patients. Am J Psychiatry 2002; 159: 460-465.

56. Lepola U, Wade A, Andersen HF. Do equivalent doses of escitalopram and citalopram have similar efficacy? A pooled analysis of two positive placebo-controlled studies in major depressive disorder. Int Clin Psychopharmacol 2004; 19: 149-155.

57. Hunter NS, Anderson KC, Cox A. Pimavanserin. Drugs Today (Barc) 2015; 51: 645-652.

58. Ballard C, Banister C, Khan Z, Cummings J, Demos G, Coate B, et al.; ADP Investigators. Evaluation of the safety, tolerability, and efficacy of pimavanserin versus placebo in patients with Alzheimer's disease psychosis: a phase 2, randomised, placebo-controlled, double-blind study. Lancet Neurol 2018; 17: 213-222.

59. Ballard C, Youakim JM, Coate B, Stankovic S. Pimavanserin in Alzheimer's disease psychosis: efficacy in patients with more pronounced psychotic symptoms. J Prev Alzheimers Dis 2019; 6: 27-33. 
60. Yunusa I, El Helou ML, Alsahali S. Pimavanserin: a novel antipsychotic with potentials to address an unmet need of older adults with dementia-related psychosis. Front Pharmacol 2020; 11: 87.

61. Grossberg GT, Kohegyi E, Mergel V, Josiassen MK, Meulien D, Hobart M, et al. Efficacy and safety of brexpiprazole for the treatment of agitation in Alzheimer's dementia: two 12-week, randomized, double-blind, placebocontrolled trials. Am J Geriatr Psychiatry 2020; 28: 383-400.

62. Devanand DP, Strickler JG, Huey ED, Crocco E, Forester BP, Husain MM, et al. Lithium treatment for agitation in Alzheimer's disease (Lit-AD): clinical rationale and study design. Contemp Clin Trials 2018; 71: 33-39.

63. Oakley H, Cole SL, Logan S, Maus E, Shao P, Craft J, et al. Intraneuronal beta-amyloid aggregates, neurodegeneration, and neuron loss in transgenic mice with five familial Alzheimer's disease mutations: potential factors in amyloid plaque formation. J Neurosci 2006; 26: 10129-10140.

64. Van Dam D, Vermeiren Y, Dekker AD, Naudé PJ, Deyn PP. Neuropsychiatric disturbances in Alzheimer's disease: what have we learned from neuropathological studies? Curr Alzheimer Res 2016; 13: 1145-1164.

65. Bieńkowski P, Glębicka A, Karaś K, Kołaczkowski M, Mierzejewski P. Spontaneous head twitches in aged rats: a correlate of late-onset "psychosis"? Int J Neuropsychopharmacol 2014; 17 Suppl 1: P-27,113.

66. Canal CE, Morgan D. Head-twitch response in rodents induced by the hallucinogen 2,5-dimethoxy-4-iodoamphetamine: a comprehensive history, a re-evaluation of mechanisms, and its utility as a model. Drug Test Anal 2012; 4: 556-576.

67. Halberstadt AL, Geyer MA. Characterization of the head-twitch response induced by hallucinogens in mice: detection of the behavior based on the dynamics of head movement. Psychopharmacology (Berl) 2013; 22: 727-739.

68. Holmes C, Arranz MJ, Powell JF, Collier DA, Lovestone S. 5- $\mathrm{HT}_{2 \mathrm{~A}}$ and 5- $\mathrm{HT}_{2 \mathrm{C}}$ receptor polymorphisms and psychopathology in late onset Alzheimer's disease. Hum Mol Genet 1998; 7: 1507-1509.

69. Woolley ML, Marsden CA, Fone KCF. 5-HT 6 receptors. Curr Drug Targets CNS Neurol Disord 2004; 3: 59-79.

70. Waters KA, Stean TO, Hammond B, Virley DJ, Upton N, Kew JN, Hussain I. Effects of the selective 5-HT re- $^{-}$ ceptor antagonist SB-269970 in animal models of psychosis and cognition. Behav Brain Res 2012; 228: 211-218.

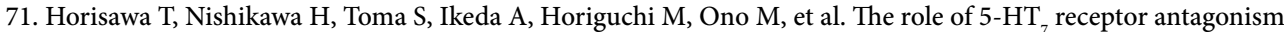
in the amelioration of MK-801-induced learning and memory deficits by the novel atypical antipsychotic drug lurasidone. Behav Brain Res 2013; 244: 66-69. 